\section{Preparing the foundation for stable gilding: the origins of materials and practices $-a$ review}

\author{
Das fundações para um douramento estável: \\ as origens dos materiais e práticas - uma revisão
}

\section{ISABEL POMBO \\ CARDOSO $\odot$}

LAQV-REQUIMTE,

Departamento de Conservação e Restauro, Faculdade de Ciências e Tecnologia, Universidade NOVA de Lisboa, Campus da Caparica, 2829-516 Caparica, Portugal

isabel.pombocardoso@gmail.com

\begin{abstract}
This paper is the fifth of a series and focuses on tracing the history of the use of gypsum based products as well as of the use of ground layers, centred on a review of published analytical evidence. The purpose is to contribute for the understanding of these long traditions which led to the choice of specific materials and practices used for producing gilding grounds in southern Europe. In fact, several practices and the raw material gypsum used in gilded surfaces do have an extremely long tradition, which can be traced back to the Pre-Pottery Neolithic B. The systematic use of these materials, especially the use of ground layers for decoration and other purposes, suggests not only an intention but also, somehow, the notion of a complex concept, the concept of a composite material, even at these very early periods, from which gilding origins. In addition, the particular case of Portugal shows that aspects such as religious, political, and sociocultural influences played a central role in the choice of gypsum as the raw material, which was curiously used exclusively for gilding.
\end{abstract}

\section{Resumo}

Este artigo, o quinto de uma série, explora a história da utilização do gesso e de camadas de preparação, baseado numa revisão de literatura com evidência analítica. O objectivo é contribuir para a compreensão destas longas tradições que estão na génese da escolha de materiais e de práticas específicas utilizadas para produzir camadas de preparação de douramento no sul da Europa. De facto, a utilização do gesso como matéria-prima bem como de certas práticas, associadas à produção de superfícies douradas, tem uma tradição extremamente longa identificando-se já no Neolítico Pré-cerâmico B. O uso sistemático desses materiais, especialmente na produção de camadas de preparação, para decoração ou outros propósitos, indiciam não só uma intenção mas também, de alguma forma, a noção de um conceito complexo, o conceito de material compósito, mesmo nestes períodos tão remotos. Por outro lado, o caso particular de Portugal revela que razões religiosas, políticas, assim como influências socioculturais, desempenharam um papel central na escolha do gesso como matéria-prima, curiosamente utilizado em exclusivo no douramento.

\section{KEYWORDS}

Gesso grounds

Gypsum plaster Lime plaster Gilding Ground layers

\section{PALAVRAS-CHAVE}

Camadas de gesso Argamassas de gesso Argamassas de cal Douramento Camadas de preparação 


\section{Introduction}

This paper is part of a set of papers arising from a research project focused on ground layers on Portuguese wooden gilded altarpieces and sculptures of the Pre-Baroque and Baroque periods. In alignment with other southern European countries, gilded and polychrome sculptures and altarpieces played a central role in the religious life of Portuguese society,since the foundation of the kingdom (12th century) up to mid-19th century, when religion shaped and infused all social, political, and cultural aspects. These southern European gilding grounds, gesso grounds, are commonly made of gypsum based materials (as aggregates) mixed with size glue (as binder) and typified by a double-layered structure. These materials and practices used to produce them were clearly aimed at obtaining long lasting and high quality gilded surfaces due to the importance of these religious objects [1-4].

Although gypsum has been used as a raw material for producing inert fillers for gilding grounds, it had and still has a different main use - a plaster material.

As part of the research it was considered essential to study the historical use of gypsum plasters, and the use of ground layers, in order to contribute to the understanding of the origins, evolution and technological choices adopted by this particular gilding technique.

\section{Brief description of gilding gesso grounds}

There is evidence that at least from the 13th to the 18th century, the gesso gilding grounds covering wooden carved objects in Portugal (as well as Spain and Italy) consisted of a double-layered structure, made of coarse gesso grosso covered with fine gesso mate, underneath a bole layer, each mixed with size glue [5]. The gesso grosso is mainly composed of synthetic anhydrite $\left(\mathrm{CaSO}_{4}\right)$, obtained by burning natural gypsum rock at high temperatures. The burning turns the rock into a soft and inert material which is then ground to a coarse powder containing a range of particle sizes (c. 5 to $250 \mu \mathrm{m}$ ). The gesso mate is mainly composed of synthetic gypsum $\left(\mathrm{CaSO}_{4} \cdot 2 \mathrm{H}_{2} \mathrm{O}\right)$, obtained by slaking the gesso grosso for several days in excess water, which produces an extremely soft material composed of very fine particles (c. 5 to $50 \mu \mathrm{m}$ ) with a lamellar/tabular-like shape.

This double-layered ground is then covered with a bole layer (a fine coloured clay). The whole forms a composite system with gradually finer and smoother particles, which provides an extremely smooth surface onto which the gold leaf is applied and burnished to produce a shiny gilded surface simulating solid gold [1-2].

\section{Brief description of lime and gypsum pre-industrial plaster technologies}

Although the focus here will be given to gypsum, both gypsum and lime plasters will be discussed because in terms of materials, production processes, and application practices they seem to have clear historical relationships. The use of these plasters has been known since the Epi-Paleolithic (c. 12,000 BC) and is considered a very important step in human technological development as they are apparently the first two products manufactured by man by harnessing the effects of heat. These plaster powders, when mixed with water, set and harden into a chemical similar state to that of the initial rock - although with a considerably lower density and with differences in the microstructure. These properties have meant that they have been used extensively throughout the human history [6-7].

Both gypsum and limestone rocks are very commonly occurring minerals in the Earth's crust. Limestones embrace a great variety of rocks composed mostly of the mineral calcite $\left(\mathrm{CaCO}_{3}\right)$. Lime plaster technology involves the burning of limestones at high temperatures, around $900^{\circ} \mathrm{C}$. This temperature initiates the decomposition of calcite to form calcium oxide $(\mathrm{CaO})$, also known as quick-lime, and the release of carbon dioxide $\left(\mathrm{CO}_{2}\right)$. This quick-lime is then slaked in excess water over a long period (initially inducing a very strong exothermic reaction) eventually becoming calcium hydroxide $\left(\mathrm{Ca}(\mathrm{OH})_{2}\right)$, known as slaked lime or lime plaster paste. The slaked lime paste is drained of excess water and mixed with aggregates (usually sand) then applied to a substrate (such as a wall). It sets and hardens by slowly reacting with atmospheric carbon dioxide $\left(\mathrm{CO}_{2}\right)$, becoming calcite again $\left(\mathrm{CaCO}_{3}\right)$, a hard and lasting material known as lime plaster.

Gypsum rock is composed mostly of the mineral gypsum (calcium sulphate dihydrate, $\mathrm{CaSO}_{4} \cdot 2 \mathrm{H}_{2} \mathrm{O}$ ). Calcium sulphate based minerals can vary in its water content, forming the different phases of the calcium sulphate-water system (see below).

Gypsum plaster technology is dependent on two characteristics of calcium sulphate: dehydration and hydration [8]. It consists of burning the gypsum rock (though at considerably lower temperatures than those required to burn limestone) which results in a burnt rock composed of different hydrated phases of calcium sulphate. This burnt rock is then ground to a powder, commonly known as gypsum plaster powder (although containing minimal amounts of gypsum). This gypsum plaster powder is simply mixed with water forming a paste; finally, the hydration leads to the fairly rapid setting and hardening. The final hardened material is gypsum $\left(\mathrm{CaSO}_{4} \cdot 2 \mathrm{H}_{2} \mathrm{O}\right)$ or gypsum with anhydrite $\left(\mathrm{CaSO}_{4} \cdot 2 \mathrm{H}_{2} \mathrm{O}\right.$ and $\mathrm{CaSO}_{4}$ ), commonly known as gypsum plaster.

\section{Dehydration and hydration processes of gypsum}

The dehydration process is as follows: when exposed to continuous heating, gypsum rock $\left(\mathrm{CaSO}_{4} \cdot 2 \mathrm{H}_{2} \mathrm{O}\right)$ begins to dehydrate losing three-quarters of its water content at around $90^{\circ} \mathrm{C}$ (between c. 90 and $250^{\circ} \mathrm{C}$ ), and gradually transforms into the hemihydrate phase $\left(\mathrm{CaSO}_{4} \cdot 0.5 \mathrm{H}_{2} \mathrm{O}\right)$. The second phase of dehydration starts at around $200^{\circ} \mathrm{C}$, when the hemihydrate gradually transforms into anhydrite III, also known as soluble anhydrite $\left(\mathrm{CaSO}_{4}\right)$, which process is complete at around $250^{\circ} \mathrm{C}$. By the time this temperature is 
reached, the transformation into anhydrite II, or insoluble anhydrite $\left(\mathrm{CaSO}_{4}\right)$, has already started (this happens between $\mathrm{c} .250$ and $1180^{\circ} \mathrm{C}$ ). Then, above $1180^{\circ} \mathrm{C}$, the anhydrite II starts to change into anhydrite $\mathrm{I}\left(\mathrm{CaSO}_{4}\right)$ and finally, at around $1385^{\circ} \mathrm{C}$, this dissociates into calcium oxide $(\mathrm{CaO})$ and sulfur trioxide $\left(\mathrm{SO}_{3}\right)$ [8-11].

The two main phases of the calcium sulphate-water system are gypsum and anhydrite II (the latter will be referred here as anhydrite), which are stable phases, either existing as natural minerals or synthesized from the natural minerals. Conversely, the hemihydrate (which also exists as a natural mineral, bassanite) and soluble anhydrite are considered metastable and can easily (particularly the soluble anhydrite which is extremely avid for water), change to the other more stable phases in the presence of humidity or heat $[8,10,12]$.

The other fundamental characteristic of gypsum, that makes it such an important material, is the ability of the gypsum plaster powder to set and harden when mixed with water and hydrated. Exactly how the hydration and setting happens is still the subject of scientific debate. The most widely accepted theory is the theory of crystallization first proposed by Le Chatelier in 1887. It suggests that the gypsum plaster powders (hemihydrates, anhydrites or a mixture) when mixed with a certain amount of water, in which they dissolve, form a supersaturated solution. From that supersaturated solution nuclei begin to precipitate and this is followed by crystal growth. The setting and hardening happens in a particular way as the new gypsum crystals develop with a needle like shape, and these intergrow, interlock and interact to produce a solid material with considerable mechanical strength $[6,8,10,13-16]$.

\section{Problems in studying the historical use of gypsum}

\section{Lack of previous research}

The study of the historical use of gypsum is not a simple task due to the scarcity and imprecision of archaeological and conservation studies.

As mentioned above, both gypsum and lime plasters are probably the two first man-made products. However, as Kingery and his colleagues state, "lime technology is a good deal more complicated [than gypsum technology] "in terms of burning temperature as well as in the number and difficulty of steps necessary to obtain the plaster paste [6, p. 221]. Because it presents a greater challenge in terms of technical achievement, lime plaster has been given much more attention than gypsum plaster.

In addition, gypsum plaster has a higher degree of deterioration than lime plaster - due to its greater solubility - so evidence of its use is scarce.

\section{Terminological imprecision}

In archaeological and conservation literature there is frequent imprecision in the use of the terminology related to gypsum technology such as the loose use of the terms plaster and gypsum.

The term plaster is used very frequently in a broad sense, to refer to both gypsum plaster and lime plaster without differentiation [e.g. 17-19]. This is despite the fact that they are distinct materials including raw materials, production processes, application practices, and behaviour. But because they also present significant similarities such as the visual appearance, the need for calcination, mixing with water, and their eventual use, this has probably contributed towards this confusion. Furthermore, both materials are commonly used together in order to enhance their individual characteristics. Thus, some lime plasters contain a variable amount of gypsum plaster powder which may have been added in order to accelerate the set, to increase the compressive strength and to reduce shrinkage of lime plaster. The opposite is also found, as frequently a variable amount of lime was added to gypsum plaster pastes to increase the workability of the pastes (the small, even sized and plate-like slaked lime particles enhance this effect), to increase the strength of the gypsum plaster and to increase its resistance to water [12, 20-23].

The term gypsum is often used to refer to several different products, including the natural gypsum rock (a mixture of several minerals but rich in calcium sulphate dihydrate mineral), the gypsum plaster powder (which can be hemihydrate, soluble anhydrite, anhydrite or a mixture of these phases), the gypsum plaster paste (gypsum plaster powder mixed with water) and the hardened gypsum plaster (which can be synthetic gypsum or synthetic gypsum with the inclusion of synthetic anhydrous particles). This contributes to the difficulty in studying gypsum technology in all its varieties. Moreover, since the mid-19th century, the industrial transformation of gypsum has been dominated by the production of the hemihydrate phase (also known as plaster of Paris). This is probably why in several published studies it has been assumed that the traditional production of gypsum plaster powders resulted in and aimed at obtaining the hemihydrate phase, and thus several authors refer to historical gypsum plaster powder as plaster of Paris [e.g. 18, 22, 24-26]. But, in fact, the major part of the final product resulting from calcination of gypsum rock in traditional kilns (where is impossible to control all the factors that influence the burning process) is anhydrite with small amounts of the other phases. The dehydration mechanism does not require very high temperatures. However, it is extremely difficult to control the process in order to obtain pure phases. Only after the industrialisation of the process has this been possible, facilitating bulk production of hemihydrates. The results of traditional calcination can vary considerably because they are dependent on several different conditions including the variety of natural gypsum, the presence of impurities, the size of the burnt lumps or stones, the length of calcination, the distance from the source of heat, and the atmospheric pressure. The main reason for the burning process being so affected by these different conditions is because gypsum is a 
poor conductor of heat. This characteristic is due to the presence of water in its composition which, during the burning process, evaporates and reduces the temperature $[8,10,12]$.

The end product, despite being composed of different phases (and usually with minimum amounts of true gypsum), is commonly called gypsum plaster powder. This explains why much of the analysis undertaken on historical gypsum plasters reveals the presence not only of gypsum but also of anhydrite crystals - because part of the anhydrite did not hydrate to gypsum during the preparation of the plaster paste (i.e. when mixed with water) [e.g. 17].

Experimental work supports this analytical evidence as burning of gypsum rock in replicas of historical kilns (Figure 1) produced a final product composed of around $75 \%$ or more of anhydrite (some lumps were composed of $100 \%$ ), $20 \%$ hemihydrate and $5 \%$ of gypsum $[10,12,27-28]$. The existence of gypsum is due to its failure to dehydrate during the calcining process. This is what usually happens to the central parts of larger lumps of gypsum rock which do not reach a high enough temperature.

It is important to emphasise that the use of multiphase gypsum plaster powders (or overburnt gypsum plasters) has three very important advantages over the use of gypsum plaster powder composed exclusively of hemihydrate. This is because the burning process influences the reactivity to water of the resulting gypsum plaster powder - burning at temperatures ranging from 90 to $250^{\circ} \mathrm{C}$ produces materials with increasing reactivity to water (hemihydrates and soluble anhydrite which set in about 15 minutes); above that $250^{\circ} \mathrm{C}$ up to $900^{\circ} \mathrm{C}$ the resultant products have a decreasing reactivity to water (which, depending on the temperature of calcination, can take up to seven days to set) $[8,10]$. Therefore, after mixing with water, the overburnt gypsum paste has a slow enough setting time to allow for the longer working time necessary, for example, for the plastering of a considerable extent of walls and ceilings, but, at the same time, it sets rapidly enough to produce a good final result. The second advantage is that it is very suitable for architectural work because it sets gradually, producing a plaster with better organized crystals thus with a low risk of cracking [8, 29]. Third, overburnt gypsum plasters are denser and consequently stronger as they are prepared with smaller amounts of water and are therefore less porous $[8,15]$.

Attaining gypsum plasters which are composed of a considerable amount of anhydrite (see below) indicates that the gypsum was, in fact, burnt at higher temperatures than the normally cited $180-200^{\circ} \mathrm{C}$. Possible explanations are the lack of temperature control in the kilns, allied to the poor heat conductivity of gypsum, or alternatively, based on their experience, the producers were intending to obtain gypsum plaster powder that would produce a better plaster for their purposes. A further hypothesis is that through long experience they knew how to separate the burnt material into different products which would be used for different purposes, as indicated in some historical documents [e.g. 30-32].

\section{Historical use of gypsum plasters and related practices - review of analytical and documentary evidence}

\section{Analytical evidence}

Archaeological studies in the Near East have identified the earliest evidence of the use of plaster (lime) during the EpiPaleolithic (c. 12,000 BC), in the Sinai Peninsula, at the site of Lagama North VIII. Though the first evidence we have of the use of plaster is of lime plaster this does not mean that gypsum plaster was not used before, or alongside it. It is possible that evidence of an early or contemporary use of gypsum plaster has not survived, due to its greater solubility, or simply has not yet been discovered. Earlier use of gypsum plaster is frequently suggested because of the ready availability of raw gypsum rock, allied to the less demanding production processes when compared to lime plaster. However, it seems that the use of lime and gypsum plasters was not widespread until the Pre-Pottery Neolithic B (c. 7,000 BC), during which plaster production and use have been identified consistently in several areas of the Near East. During the Neolithic period, plaster pastes were used for architectural purposes and for utilitarian as well as ritual and decorative items [6, 17, 33-36].

In addition to the widespread use of plaster technology during the Pre-Pottery Neolithic B, it is interesting to note a clearly separate spatial distribution, with gypsum plaster being identified in the drainage area of the Tigris and Euphrates, and further East, while lime plaster is found in the Levant and Anatolia. It is suggested that the reasons for this differentiation are related to the availability of the raw materials - fuel, calcite, and gypsum -, but also to social and economic aspects [6-7, 17-18, 33-36].

The following is a summary of the analytical evidence for the use of gypsum plaster as a ground layer as reported by different authors.

In the Pre-Pottery Neolithic B, at various sites in the Near East, gypsum plaster is reported to have been used as a ground layer for floors, walls, on pottery vessels, tablets as support for writing, and on a figurine $[6,17,33,37]$. It was used extensively in Egypt [17, 38-41].

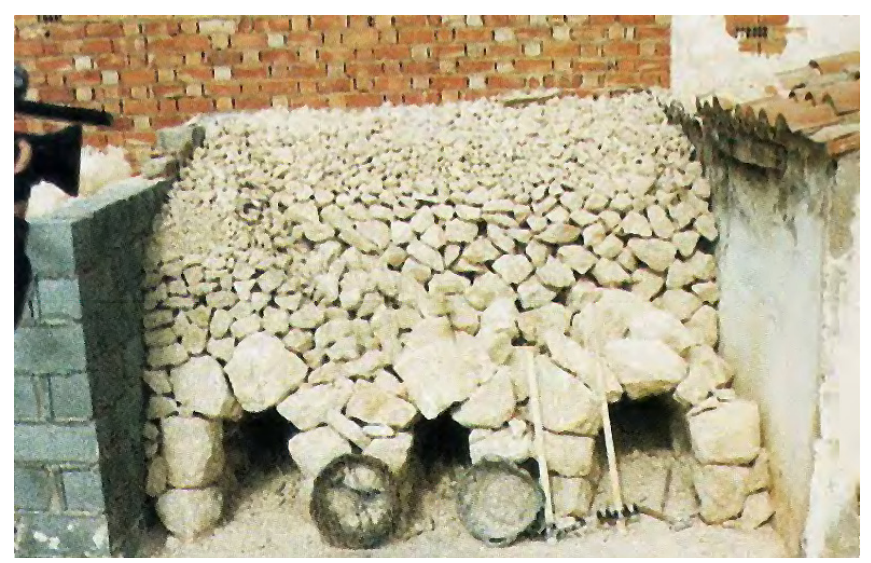

Figure 1. Replica of a gypsum kiln according to Turriano's information [28]. 
During the Roman Period, gypsum plaster was definitely known and used [e.g. 42-43]. Though the Romans had a stronger tradition of using lime plaster, it is believed that the Roman Empire contributed to the spread of gypsum plaster technology throughout Europe.

In the actual territory of Spain, there is evidence of the use of gypsum plaster as a ground layer prior to the Roman Period, at least since Early Iron Age [44-46]. Its traditional use seems to have been consolidated from the Roman influence but also, and chiefly, from the Islamic influence which spread through North Africa [44, 47-50]. Islamic cultures had a long tradition of using gypsum plaster [eg. 51] and they occupied the southern area of the Iberian Peninsula from the beginning of the $8^{\text {th }}$ century until the end of the 15 th century.

Regular examples are found on samples dating from the Medieval period up to the 19th century in Europe [12, 22-23, $44-45,48,50,52-65]$.

\section{The choice of overburnt gypsum}

Several samples of these gypsum plasters, when analysed in detail, were revealed to have been overcalcined [12, 17, 22-23, 28, 38-39, 41, 47, 52, 55-56, 58-63, 65-67].

Among these frequent examples of historical gypsum plasters, there are some surprising ones found in Germany and Italy (overburnt gypsum with small amounts of lime) which were applied onto exterior walls but are still in very good condition [23, 56, 57, 61-62]. This is surprising because, due to its solubility (around $2 \mathrm{~g}$ per litre), gypsum is commonly considered unsuitable for use on external surfaces except in very dry countries [e.g. 6, 18, 21].

These particular exterior gypsum plasters are of great interest as they seem to contradict this established theory. Analysis of these gypsum plasters showed the presence of gypsum with larger crystals than usual (instead of needle like crystals the crystals are tabular in shape), as well as anhydrite crystals and calcium carbonate crystals. The growth of gypsum crystals with time, the lower solubility of anhydrite and calcite crystals and greater density of these plasters contributed to their resistance to exposure to weathering conditions $[6,23,56-57]$.

There are other and even more interesting examples of overburnt gypsum plasters because they make no use of lime and are also used on external walls in Spain. These examples - reported by Sanz \& Villanueva [66], Sanz [12, 28, 47], Villanueva and colleagues [68] and Villanueva [58] - also have a good degree of durability, as several have survived in good condition. The common feature of durable and waterresistant gypsum plasters seems to be the presence of stable anhydrite crystals, i.e. plasters made of gypsum rock burnt at high temperatures that are less prone to cracking, less porous, less soluble, and stronger.

\section{Documentary evidence}

Documentary evidence also attests to the continuous use of gypsum plaster.
In historical documentation, gypsum rock or its use is described in several documents. The first example shows in Ancient Mesopotamian literature, where references to the use of gypsum not just as a casting and moulding material but also as a ground layer for statues and other objects [69]. After this, the earliest description of gypsum is given by Theophrastus, around $314 \mathrm{BC}$, which describes the gypsum used for plaster, with an interesting reference to the possibility of its reuse [70]. Vitruvius, in 27-16 BC, describes it as special important for vaulting [71] and Pliny, in $79 \mathrm{AD}$, also refers to it [72]. Julian of Ascalon, in his treatise, mentions the existence of gypsum kilns [73]. After these, Alberti (1452) [74], Biringuccio (1540) [75], Agricola (1546) [76], Turriano (1511-1583) [77], Diderot [28], Bélidor 1729 [30], Montamy (1765) [78], Rondelet (1802) [31] and Castro (1812-1820) [32] are other very important examples where several aspects of the gypsum and of its preparation are described.

The use of gypsum for gilding grounds is also regular in painting/gilding treatises [1].

\section{Evidence of transference of practices}

Just as important as the historical use of gypsum as a raw material, is the historical use of practices similar to those identified on gilded surfaces, which show the transference not only of materials but also of practices among different technologies.

These methods include, as in all the cases mentioned before, the frequent use of gypsum and lime plasters as ground layers. The critical functions of ground layers are to prepare the surface to receive the decoration, to produce a high quality decoration as well as to promote its durability [3-4].

The slaking of the powders in order to modify the characteristics of the products is another process transferred among technologies. The long slaking period of calcium hydroxide pastes has the purpose of improving the quality of the lime plaster considerably by reducing the size of the particles and increasing the formation of plate like particles, thus creating a larger reactive surface area. This particle shape and size also increases the plasticity of the paste, improving its workability; it speeds the carbonation rate, as well as increasing the final strength of the mortar [6, 79-80]. The slaking process is also used for producing gesso mate powders in order to achieve extremely small and lamellar gypsum particles which have a vital impact on quality and durability of gilded and polychrome surfaces, although through different mechanisms [2-4].

The use of plaster pastes mixed with aggregates (usually sand), frequently applied in consecutive layers that are gradually finer and smoother, again aim at quality and durability of the decorations. In the same way, the southern European gesso grounds make use of different particle size powders as aggregates (gesso grosso, gesso mate, and bole) mixed with size glue, creating a composite structure in order to achieve to achieve similar effects. 
And finally, there is also evidence of burnishing used on these surfaces $[1,6-7,80]$. All these practices can be identified in the gilded grounds. These suggest that the concept of a composite coating product and other practices which make use of highly skilled craft practices were somehow perceived/understood even at these very early periods, and that it is from these practices that the gilded grounds probably trace their origins.

\section{The curious case of the use of gypsum plaster in Portugal}

Some Portuguese studies refer to the early widespread use of gypsum plaster in the actual Portuguese territory (from Classical Antiquity) as an established fact [e.g. 81-83]. However, with three exceptions [84-86] where gypsum plaster was identified, so far there is no analytical evidence to support the widespread use of gypsum in Portugal. The documentary and analytical evidence for the common use of gypsum for plastering in Portugal date from the end of the 18th century and later. The earlier examples of the use of gypsum plaster mentioned above date from the 12th century, during the Islamic domination of the south of Portugal, and belong to the remains of a mosque in Mértola and of a Castle in Silves. The other one dates from the beginning of the 16th century and is from a very significant monument in Tomar. These particular examples do indicate the early use of gypsum plaster; however, isolated cases alone cannot be taken as indicative of its widespread use. These are isolated examples as they are from particular monuments and with established links to Islamic artisans. Moreover, a study of various Portuguese documents [1], as for example dictionaries and construction and architecture treatises, showed that mention of the use of gypsum plaster is extremely scarce compared with the many references to the use of lime plaster. Before the end of the 18th century, apart from minor passing references in Bluteau's dictionary (1713) [87] and in a construction book by Valério Martins de Oliveira (1748) [88], there were not found references to gypsum plaster in any of the construction treatises or contracts consulted. Moreover, there are two references to gypsum which reinforce its nonwidespread use. Indeed, the references by Sales (1759) [89] and by Machado (1823) [90] in their dictionaries refer that gypsum was not in use in Portugal for construction and to the lack of good supply of gypsum. On the other hand, plenty of references were found to the production and use of lime, as well as contracts requiring its use. Additionally, in the documents that regulated the different mechanical professions [91-93], there are no references to professions related to the production, sale, transport or use of gypsum plaster, in contrast to professions connected with the production and work with lime plaster.

Other studies indicate that gypsum plaster was introduced only in the 18th century, which seems more likely
[94-95]. What is established is that the use of gypsum plaster for wall plastering was widespread by the end of the 18th century. This was, in the view of some authors, due to Italian influence, through the arrival in Portugal of the renowned Italian artist Giovanni Grossi and other Italian artists who were responsible for several important decorative schemes in Portugal. The creation of a gypsum plaster school in Lisbon during 1764 also indicates that this decorative art was flourishing and certainly contributed to its thriving [9596]. Is important to point out that the devastating earthquake of 1755 in the south and centre of Portugal, including Lisbon, was the cause for the enormous expansion of building verified during this period. The reconstruction of Lisbon included the introduction of several unconventional aspects. It would be interesting to further research probable influences of the earthquake and consequent extensive and revolutionary rebuilding on the spread of the use of gypsum plaster, as gypsum plaster presents several advantages, particularly important due to this unusual event, being one is its known good performance on fire resistance [22] and another the demand of less energy for its production when compared with lime.

The lack of sufficient analytical evidence prior to the end of the 18th century agrees with the lack of natural gypsum rock in Portugal and, in the view of some authors, this is a direct relationship. However, this cannot be considered as the only reason since there is some gypsum in Portugal (though grey), and access to natural gypsum was possible as nearby countries, with known commercial contacts, have good gypsum rock supplies (Spain, France and Morocco). Furthermore, there is documentary and analytical evidence of the extensive use of gypsum as the raw material for the gesso grounds since the 13th century [1-2].

This indicates that the widespread use of gypsum as a raw material was limited to the gesso grounds when gilded surfaces were fulfilling an important religious social and political role and that there was a lack of an established tradition of the use of gypsum for plastering, which normally involved the use of lime. By the end of the 18th century and throughout the 19th century, when gilding loses importance, gesso grounds are substituted for chalk grounds; at the same time the use of gypsum for interior wall plastering gain relevance.

\section{Conclusions}

The use of gypsum, the use of ground layers, the slaking, the ground layers made with gradually finer fillers, followed by decoration and burnishing, are practices identified in the Portuguese gilding technique. This material and these practices are part of a very long tradition that can be traced back to the plasters technologies used in the Pre-Pottery Neolithic $B$ in the Near East, when there is evidence of the widespread use of gypsum as a raw material and as a ground layer. The concept of a composite coating and other practices that reveal 
highly skilled craft activity can be identified even at these very early periods, from which the southern European gesso grounds may trace their origins.

Ground layers were burnished and decorated and seem to have had a continuous use in European countries since at least the Roman Period.

Gypsum rock was apparently burnt at high temperatures despite the frequent references that it was burnt only at low temperatures. This is supported by the archaeological evidence, which shows the presence of anhydrite crystals in historical gypsum plaster samples, and also by experimental studies using replicas of ancient kilns. Calcination at high temperatures could result either from lack of control of the temperatures in the kilns, allied to the poor heat conductivity of gypsum, or from a deliberate operation, since gypsum plaster pastes made with overburnt gypsum plaster powders are easier to apply due to their longer setting time and they result in a more stable, stronger and durable plaster.

Finally, there is little evidence for the widespread use of gypsum rock in Portugal for the production of gypsum plaster before the later part of the 18th century, despite its use for the gesso layers in the gilded Portuguese altarpieces probably from the 13th century. This was probably influenced by the strong cultural tradition of using lime plaster, which progressively changed, possibly as a consequence of the 1755 earthquake.

\section{Acknowledgments}

I would particularly like to thank Prof. Elizabeth Pye and Prof. Clifford Price. This work was funded by the Portuguese State through Fundação para a Ciência e a Tecnologia [SFRH/BD/23349/2005] and [SFRH/BDP/73281/2010] in support of $\mathrm{PhD}$ research at the Institute of Archaeology, University College London, and post-doc LAQV-REQUIMTE. This work was also supported by the Associate Laboratory for Green Chemistry-LAQV which is financed by national funds from FCT/MCTES (UID/QUI/50006/2013) and co-financed by the ERDF under the PT2020 Partnership Agreement (POCI-01-0145-FEDER-007265).

\section{REFERENCES}

1. Pombo Cardoso, I.; Pye, E., 'Gessoes in Portuguese Baroque gilding grounds. Part 1: a study of historical documentary sources', Studies in Conservation 62(4) (2017) 185-209, http:// dx.doi.org/10.1080/00393630.2015.1130774.

2. Pombo Cardoso, I.; Pye, E., 'Gessoes in Portuguese Baroque gilding grounds. Part 2: analytical study of historical samples and archaeological reconstructions', Studies in Conservation 63(2) (2018) 72-96, http://dx.doi.org/10.1080/00393630.2016.1266430.

3. Pombo Cardoso, I.; Pye, E., 'Preparing the foundation for stable gilding: scientific evaluation of the durability of Baroque gesso gilding grounds', Journal of Archaeological Science 79 (2017) 86-95, http://dx.doi.org/10.1016/j. jas.2017.01.014.

4. Pombo Cardoso, I.; Pye, E., 'Preparing the foundation for stable gilding: Baroque craftsmen's empirical understanding of gesso gilding grounds', Journal of Archaeological Science 79 (2017) 96-106, http://dx.doi.org/10.1016/j.jas.2017.01.015.

5. Pombo Cardoso, I.; Sá, S, 'The use of ground layers on gilded and polychrome surfaces. A Review' (forthcoming).
6. Kingery, W.; Vandiver, P.; Prickett, M., 'The beginnings of pyrotechnology, Part II: production and use of lime and gypsum plaster in the pre pottery Neolithic Near East', Journal of Field Archaeology 15(2) (1988) 219-244 https://doi. org/10.1179/009346988791974501.

7. Rollefson, G. O., 'The uses of plaster at neolithic 'ain ghazal, Jordan', Archaeomaterials 4 (1990) 33-54.

8. Wirsching, F., 'Calcium sulphate', in Ullmann's Encyclopedia of Industrial Chemistry, Wiley-VCH (2000), https://doi. org/10.1002/14356007.a04_555.

9. West, R. R.; Sutton, W. J., 'Thermography of gypsum', Journal of American Ceramic Society 37(5) (1954) 221-224, https:// doi. org/10.1111/j.1151-2916.1954.tb14027.x.

10. Syndicat National des Industries du Plâtre, Le Plâtre. PhysicoChimie. Fabrication et Emplois, Eyrolles, Paris (1982).

11. Chlouveraki, S., 'Gypsum in Minoan architecture. Exploitation, utilisation and weathering of a prestige stone', tese de doutoramento, University College London, London (2006).

12. Sanz, D., 'Análisis del yeso empleado en revestimientos exteriores mediante técnicas geológicas', tese de doutoramento, Universidad Politécnica de Madrid, Madrid (2009), http:// oa.upm.es/1711/ (acesso em 2019-1-25).

13. Amathieu, L.; Boistelle, R., 'Improvement of the mechanical properties of set plasters by means of four organic additives inducing \{101\} faces', Journal of Crystal Growth, 79(1-3) (1986) 169-177, https://doi.org/10.1016/0022-0248(86)90432-X.

14. Torraca, G., Materiaux de Construction Poreux, ICCROM, Rome (1986).

15. Lewry, A.; Williamson, J., 'The setting of gypsum plaster. Part II. The development of microstructure and strength', Journal of Materials Science 29 (1994) 5524-5528, https://doi.org/10.1007/ bfoo349943.

16. Finot, E.; Lesniewska,E.; Mutin, J.; Goudonnet, J., 'Investigations of surface forces between gypsum microcrystals in air using atomic force microscopy', Langmuir 16 (2000) 4237-4244, https://doi.org/10.1021/ la9902439.

17. Gourdin, W. H.; Kingery, W. D., 'The beginnings of pyrotechnology: Neolithic and Egyptian lime plaster', Journal of Field Archaeology 2(1-2) (1975) 133-150, https:// doi. org/10.1179/009346975791491277.

18. Moorey, P. R. S., Ancient Mesopotamian Materials and Industries. The Archaeological Evidence, Clarendon Press, Oxford (1994).

19. Ling, R., Stucco Work and Painting in Roman Italy, Ashgate, Aldershot (1999).

20. Andrews, H., 'Gypsum and anhydrite plasters', National Building Studies Bulletin 6 (1948).

21. Colonial Liaison Section of the Building Research Station, 'The uses of gypsum and anhydrite in building', Colonial Building Notes 33 (1955) 1-13.

22. Karni, J.; Karni, E., 'Gypsum in construction: origin and properties', Materials and Structures 28 (1995) 92-100, https://doi. org/10.1007/bfo2473176.

23. Middendorf, B., 'Physico-mechanical and microstructural characteristics of historic and restoration mortars based on gypsum: current knowledge and perspective', in Natural Stone, Weathering Phenomena, Conservation Strategies and Case Studies, ed. S. Siegesmund, T. Weiss \& A. Vollbrecht, The Geological Society, London (2002) 165-176, https://doi.org/10.1144/GSL. SP.2002.205.01.13. 
24. Thomson Jr, D.V., The Craftsman's Handbook. "Il Libro dell' Arte." Cenino d'Andrea Cennini, Dover Publications, New York (1933).

25. Lucas, A.; Harris, J., Ancient Egyptian Materials and Industries, E. Arnold, London (1962).

26. Forbes, R. J., Studies in Ancient Technology, 2nd ed., E. J. Brill, Leiden (1965).

27. Vogel, D.; Follner, H.; Jacobi, H.; Kulke, H.; Brokmeier, H.-G., 'Characterization and reproduction of historical gypsum plasters and comparison with familiar modern preparations', ZKG International 52(11) (1999) 640-648.

28. Sanz, D., 'Traditional gypsum kilns', Recopar 5 (2005) 76-84, http://polired.upm.es/index.php/recopar/article/view/2186 (acesso em 2019-1-25).

29. Murat, M.; Pusztaszeri, L.; Gremion, M., 'Corrélations "texture cristalline-propriétés mécaniques” des plâtres durcis. Étude préliminaire', Materials and Structures 8(5) (1975) 377-385, https://doi.org/10.1007/bfo2479025.

30. Belidor, B. F., La Science des Ingénieurs dans la Conduite des Travaux de Fortification et d'Architecture Civile, Paris (1729), http://gallica.bnf.fr/ark:/12148/bpt6k856819 (acesso em 2019-1-25).

31. Rondelet, J., Traité Théorique et Pratique de l'Art de Bâtir, vol. 1, Paris (1802), https://gallica.bnf.fr/ark:/12148/bpt6k86635c (acesso em 2019-1-25).

32. Machado de Castro, J. M., Dicionário de Escultura: Inéditos de História de Arte, Livraria Coelho, Lisboa (1937).

33. Thuesen, I.; Leonardsen, E.; Rehhoff, L.; Akkermans, P., 'Gypsum or calcite? A preliminary case study of Syrian plasters', Paléorient 16(2) (1990) 79-87, https://doi.org/10.3406/ paleo.1990.4534.

34. Goren,Y.; Goldberg, P., 'Petrographic thin sections and the development of Neolithic plaster production in Northern Israel', Journal of Field Archaeology 18(1) (1991) 131-140, https:// doi.org/10.1179/009346991791548735.

35. Goren, Y.; Segal, I.; Bar-Yosef, O., 'Plaster artifacts and the interpretation of the Nahal Hemar Cave', Journal of The Israel Prehistoric Society 25 (1993) 120-131.

36. Hauptmann, A.; Yalcin, Ü., 'Lime plaster, cement and the first puzzolanic reaction', Paléorient 26(2) (2000) 61-68, https://doi. org/10.3406/paleo.2000.4710.

37. Nissen, H., 'The archaic texts from Uruk', World Archaeology 17(3) (1986) 317-334, https://doi.org/10.1080/00438243.1986. 9979973.

38. Ghorab, H,; Ragai, J.; Antar, A., 'Surface and bulk properties of ancient Egyptian mortars. Part I: X-ray diffraction studie', Cement and Concrete Research 16 (1986) 813-822, https://doi. org/10.1016/0008-8846(86)90004-9.

39. Regourd, M.; Kerisel, J.; Deletie, P.; Haguenauer, B., 'Microstructure of mortars from three Egyptian pyramids', Cement and Concrete Research 18 (1988) 81-90, https://doi. org/10.1016/0008-8846(88)90124-X.

40. Klemm, D.; Klemm, R., 'Mortar evolution in the Old Kingdom of Egypt', in Archaeometry '90, ed. E. Pernicka \& G. A. Wagner, Birkhäuser Verlag, Basel (1990) 445-455.

41. Martinet, G., 'Caracterisation des mortiers pharaoniques du temple d'Amon à Karnak', Bulletin de Liaisons Laboratoires des Ponts et Chaussés 181 (1992) 39-45.
42. Tsakiridis, P.; Toumbakari, E., 'Characterisation of ancient gypsum mortars from the archaeological site of Amathus, Cyprus', in Historic Mortars and RILEM TC 203-RHM Final Workshop, ed. J. Válek, C. Groot \& J. J. Hughes, RILEM, Bagneux (2010) 373-380.

43. Tucci, P., 'Red-painted stones in Roman architecture', American Journal of Archaeology 115(4) (2011) 589-610, https:// doi.org/10.3764/aja.115.4.0589.

44. Marzo, P., Alloza, R.; Iglesias, P., Recuenco, J. L., 'Estudio arqueométrico de los morteros y materiales de construcción', in Los Poblados del Bronce Final y Primera Edad del Hierro del Cabezo de la Cruz (La Muela, Zaragoza), ed. J. V. Picazo \& J. M. Rodanés, Gobierno de Aragón, Zaragoza (2009) 331-343.

45. Parras-Guijarro, D.; Montejo-Gámez, M.; Ramos-Martos, M.; Sánchez, A., 'Analysis of pigments and coverings by X-ray diffraction (XRD) and micro Raman spectroscopy (MRS) in the cemetery of Tutugi (Galera, Granada, Spain) and the settlement convento 2 (Montemayor, Córdoba, Spain)', Spectrochimica Acta. Part A: Molecular and Biomolecular Spectroscoy 64(5) (2006) 1133-1141, https://doi.org/10.1016/j. saa.2005.11.035.

46. Gómez, M.; Vicente, J.; Martín, C.; Egido, M., Algueró, M., González, E.; Arteaga, A. Juanes, D., 'Revisión y actualización de análisis de la policromía de la Dama de Baza. Comparación can la Dama de Elche', Bienes Culturales. Revista del Instituto del Patrimonio Histórico Español 8 (2008) 211-222.

47. Sanz, D., 'Caracterización de los morteros del yacimiento islámico de los Casares (Riba de Saelices, Guadalajara)', relatório, Universidad Politécnica de Madrid, Madrid (2002).

48. Genestar, C.; Pons, C., 'Ancient covering plaster mortars from several convents and Islamic and Gothic palaces in Palma de Mallorca (Spain). Analytical characterization', Journal of Cultural Heritage 4 (2003) 291-298, https://doi.org/10.1016/j. culher.2003.02.001.

49. Cardell-Fernández, C.; Navarrete-Aguilera, C., 'Pigment and plasterwork analyses of Nasrid polychromed lacework stucco in the Alhambra (Granada, Spain)', Studies in Conservation 51 (2006) 161-176, https://doi.org/10.1179/sic.2006.51.3.161.

50. Romero-Pastor, J.; Duran, A.; Basilio, A., Van Grieken, R., Cardell, C., 'Compositional and quantitative microtextural characterization of historic paintings by micro-X-ray diffraction and Raman microscopy', Analytical Chemistry 83 (2011) 8420-8428, https://doi.org/10.1021/ac201159e.

51. Oudbashi, O.; Shekofte, A., 'Traditional methods of gypsum production in province of Khuzestan, southwest of Iran', in HMC08, Historical Mortars Conference Characterization, Diagnosis, Conservation, Repair and Compatibility, LNEC, Lisboa (2008), https://www.researchgate.net/ publication/236986738 (acesso em 2019-1-25).

52. Kawiak, T., 'Gypsum mortars from a twelfth-century church in Wislica, Poland', Studies in Conservation 36 (1991) 142-150, https://doi.org/10.2307/1506419.

53. Adams, J.; Kneller, W.; Dollimore, D., 'Thermal analysis (TA) of lime and gypsum-based medieval mortars', Thermochimica Acta 211 (1992) 93-106, https://doi. org/10.1016/0040-6031(92)87010-8. 
54. Capitan-Vallvey, L.; Manzano, E.; Medina Florez, V., 'A study of the materials in the mural paintings at the 'Corral del Carbon' in Granada, Spain', Studies in Conservation 39(2) (1994) 87-99, https://doi.org/10.1179/sic.1994.39.2.87.

55. Middendorf, B.; Knofel, D., 'Characterization of historic mortars from buildings in Germany and the Netherlands', in Conservation of Historic Bricks Structures: Case Studies and Reports of Research, ed. N. S. Baer, S. Fitz \& R. A. Livingston, Donhead, Shaftesbury (1998) 179-196.

56. Middendorf, B.; Knofel, D., 'Gypsum and lime mortars of historic German brick buildings. Analytical results and restoration material requirements', in Conservation of Historic Bricks Structures: Case Studies and Reports of Research, ed. N. S. Baer, S. Fitz \& R. A. Livingston, Donhead, Shaftesbury (1998) 197-208.

57. Middendorf, B.; Knofel, D., 'Water-resistant gypsum lime mortars for the restoration of historic brick buildings', in Conservation of Historic Bricks Structures: Case Studies and Reports of Research, ed. N. S. Baer, S. Fitz \& R. A. Livingston, Donhead, Shaftesbury (1998) 311-324.

58. Villanueva, L., 'Yesos tradicionales', in Actas de la V Jornada de Aplicaciones Arquitectónicas de Materiales Compuestos y Aditivados, Madrid (1999).

59. Colston, B.; Watt, D.; Goode, A., 'Analysis of historic lime and gypsum floors - Part two', Journal of Architectural Conservation 8(2) (2002) 47-68, https://doi.org/10.1080/1355 6207.2002.10785319.

60. Fisher, H.; Vtorov, B., 'Characterization of historical gypsum mortars', ZKG International 55(5) (2002) 92-99.

61. Lucas, G., 'High-temperature gypsum plaster on historic exteriors? A plea for Gypsum', ZKG International 56(08/09) (2003) 78-86.

62. Lucas, G., 'The special features of high-temperature gypsum mortar as a building material', ZKG International 56(08/09) (2003) 54-65.

63. Bustamante, R.; Sánchez de Rojas, M., 'Study of plaster finishes on San Pedro de los Francos church at Calatayud', Materiales de Construcción 57(286) (2007) 53-64, https://doi. org/10.3989/mc.2007.v57.i286.47.

64. Lluveras, A.; Boularand,S.; Roqué, J.; Cotte, M.; Giráldez, P.; Vendrell-Saz, M., 'Weathering of gilding decorations investigated by SR: development and distribution of calcium oxalates in the case of Sant Benet de Bages (Barcelona, Spain)', Applied Physics A 90(1) (2008) 23-33, https://doi.org/10.1007/ s00339-007-4228-x.

65. Vela, F.; Sanz, D.; López, S., 'Survey and characterization of historical mortars of the church of San Pedro Apóstol in Polvoranca (Leganés, Madrid). Constructive aspects and petrological analysis', in HMCO8, Historical Mortars Conference Characterization, Diagnosis, Conservation, Repair and Compatibility, LNEC, Lisboa (2008), http://oa.upm. es/4233/ (acesso em 2019-1-25).

66. Sanz, D.; Villanueva, L., 'Albarracín y el Yeso Rojo', Informes de la Construcción 56(493) (2004) 47-52, https://doi.org/10.3989/ ic.2004.v56.i493.439.

67. Sanz, D.; Villanueva, L., 'Evolución de los morteros históricos de yeso al exterior en la España Central', in Actas del Sexto Congreso Nacional de Historia de la Construcción, ed. S. Huerta, R. Marín, R. Soler \& A. Zaragozá, vol. 2, Instituto Juan de Herrera, Madrid (2009) 1329-1336.
68. Villanueva, L.; Mora, S. ; Sanz, D., 'La construcción medieval y renacentista en las puertas del conjunto amurallado de Moya (Cuenca). Materiales históricos y técnicas Constructivas', in Actas del IV Congreso Nacional de Historia de la Construcción, Instituto Juan de Herrera, Madrid (2005) 1115-1121.

69. Levey, M., 'Gypsum, salt and soda in ancient Mesopotamian chemical technology', Isis 49(3) (1958) 336-342.

70. Theophrastus, Theophrastus on Stones, trad. E.R. Caley \& J.F.C. Richards, Ohio State University, Ohio (1956).

71. Vitruvius, Ten Books on Architecture, trad. I. D. Rowland \& T. N. Howe, Cambridge University Press, Cambridge (1999).

72. Pliny, Pliny. Natural History, trad. H. Rackham, Heinemann, London (1952).

73. Hakim, B.; 'Julian of Ascalon's treatise of construction and design rules from sixth-century Palestine', Journal of the Society of Architectural Historians 60(1) (2001) 4-25, https:/ doi. org/10.2307/991676.

74. Leoni, J., The Architecture of Leon Batista Alberti. In ten books. Ofpainting. In three books. And of statuary. In one book, London (1755).

75. Cyril; S.; Gnudi, M.; Biringuccio, V., The pirotechnia (1540), Reprint of edition originally published in 1942, Basic Books, New York (1959).

76. Bandy, M.; Bandy, J., Georgius Agricola: De Natura Fossilium, Dover Publications, New York (2004).

77. Turriano, J., The Twenty-one Books of Engineering and Machines of Juanelo Turriano, trad. A. Keller, Doce Calles, Madrid (1996).

78. Montamy, D. F., 'Mémoire sur le stuc', in Traité des Couleurs Pour la Peinture en Émail et sur la Porcelaine, Paris (1765) 200-210.

79. Rodríguez-Navarro, C.; Hansen, E.; Ginell, W. S., 'Calcium hydroxide crystal evolution upon aging of lime putty', Journal of American Ceramic Society 81 (1998) 3032-3034, https://doi. org/10.1111/j.1151-2916.1998.tbo2735.x.

80. Ruiz-Agudo, E.; Rodríguez-Navarro, C., 'Microstructure and rheology of lime putty', Langmuir 16 (2010) 3868-3677, https:// doi.org/10.1021/la903430z.

81. Aguiar, J., Cor e Cidade Histórica. Estudos Cromáticos e Conservação do Património, FAUP, Porto (2002).

82. Cotrim, H., 'Reabilitação de estuques antigos', tese de mestrado, Instituto Superior Técnico, Lisboa (2005).

83. Silveira, P. M.; Veiga, M. R.; Brito, J., 'Gypsum coatings in ancient buildings', Construction and Building Materials 21 (2007) 126-131, https://doi.org/10.1016/j. conbuildmat.2005.06.035.

84. Freire, T.; Santos Silva, A.; Veiga, R., 'Caracterização de revestimentos interiores antigos portugueses', in HMCO8, Historical Mortars Conference Characterization, Diagnosis, Conservation, Repair and Compatibility, LNEC, Lisboa (2008), https://www. researchgate.net/publication/271072546 (acesso em 2019-1-25).

85. Santos Silva, A.; Veiga, R.; Adriano, P.; Magalhães, A.; Pires, J.; Carvalho, A.; Cruz, A. J.; Mirão, J.; Candeias, A., 'Characterization of historical mortars from Alentejo's religious buildings', International Journal of Architectural Heritage 4(2) (2010) 138-154, https://doi.org/10.1080/15583050903046322.

86. Afonso, L. U., 'De rotunda a charola: a etapa manuelina', in A Charola do Convento de Cristo: História e Restauro, ed. A.C. Dias \& I. Frazão, DGPC, Lisboa (2014) 70-159. 
87. Bluteau, D.R., Vocabulario Portuguez e Latino, Collegio Artes Companhia de Jesus, Coimbra (1713), http://purl.pt/13969.

88. Oliveira, V., Advertências aos Modernos que Aprendem os Officios de Pedreiro e Carpinteiro, Officina de Antonio da Sylva, Lisboa (1748).

89. Sales, A. J., 'Dicionário do comércio', manuscrito, Biblioteca Nacional de Portugal, Lisboa (1759), http://purl.pt/13945.

90. Machado, C. V., Collecção de Memorias Relativas às Vidas dos Pintores, Esculptores, Architectos e Gravadores Portuguezes, Lisboa (1823).

91. Correia, V., Regimentos dos Oficiais Mecânicos da Mui Nobre e Sempre Leal Cidade de Lisboa (1572), Imprensa da Universidade, Coimbra (1926).

92. Langhans, F., As Corporações dos Ofícios Mecânicos. Subsídios para a sua História, Imprensa Nacional de Lisboa, Lisboa (1943).

93. Langhans, F., As Corporações dos Ofícios Mecânicos. Subsídios para a sua História, Imprensa Nacional de Lisboa, Lisboa (1946).

94. Segurado, J. E., Acabamentos das Construções, Livraria Aillaud e Bertrand, Lisboa (1900).

95. Vieira, E., 'Técnicas tradicionais de fingidos e de estuques no norte de Portugal. Contributos para o seu estudo e conservação', tese de mestrado, Universidade de Évora, Évora (2002).

96. Silva, H. T., 'Giovanni Grossi e a evolução dos estuques decorativos no Portugal setecentista', tese de mestrado, Universidade de Lisboa, Lisboa (2005).
RECEIVED: 2018.7.31

REVISED: 2018.11 .19

ACCEPTED: 2018.12.1

ONLINE: 2019.1.26

\section{(1) $\Theta \Theta$}

This work is licensed under the Creative Commons Attribution-NonCommercial-NoDerivatives 4.0 International License. To view a copy of this license, visit

http://creativecommons.org/licenses/by-nc-nd/4.o/deed.en. 